\title{
PBL Implementation in History Study Groups Integrated With Javanese Culture
}

\author{
Winahyu Adha Yuniyati ${ }^{1}$, Leo Agung $S^{1}$, Warto $^{1}$ \\ ${ }^{1}$ Department of History Education, Sebelas Maret University \\ Email: winahyu_11@yahoo.co.id
}

\begin{abstract}
Javanese culture are a way of living that will always evolve, this culture belongs to the people of Java and will be passed down to the next generation. The high schoolers often forgot the Javanese culture, so there need to be a lesson on the way to solve problems, in school. The goal of this research is to give a description of the success of the high school students in studying history through the making of groups based on Javanese culture integration. The process of making this group can also introduce Javanese culture to the next generation as a way of loving our country. This research used qualitative descriptive method through observation and with enrichment of deeper understanding of literatures as media for collecting data. The result can be seen in the result of the high school students study with integrating Javanese culture, so the students will be able to up their achievement through group study and add to their knowledge of Javanese culture that we have to preserve.
\end{abstract}

Keywords: Problem Based Learning; Javanese Culture; Teaching History

\section{INTRODUCTION}

Java is one of many islands in Indonesia. The island of Java is among islands with special culture in Indonesia, so there need to be empathy to its existence. Javanese cultures are sacred because there are many important elements that have been sanctified [1].

Javanese culture holds many sacred valves that should be applied in daily life. The application of Javanese culture in daily life are mandatory to its people, it is important because it is a way to preserve and introduce the wealth of Java. Applications of Javanese culture don't have to be in formal way like region and tradition but it can also be expressed in all way.

Application of Javanese cultures in daily life are effective to the next generation when in school. School is a place where the hope of our future met with the purpose to seek knowledge. So it is proper that the integration of Javanese culture be applied in school environment. Integration of Javanese cultures that was applied in school was the combination of many cultures with the process of learning in many level of education. Education level in Indonesia are so varying, it adjusted to the age of students [2]. Determining the age of students of every level adjusted with ministerial 
regulation of national education that is being refitted every year. In every levels there are different challenges compatible to the problems that is being based on.

Problems we often have when learning in school, primarily the integration of Javanese culture usually comes to high school student. Students at the age of high school often forgot their own culture they even thought that Javanese cultures are unable to follow with current development. The result is that many high school students forgot the Javanese culture. This problem is mainly caused by modernization moreover in this world without limitation.

Based on the challenges stated in previous paragraph, it can be analyzed that the difficulty of integrating Javanese culture in school is caused by modernization that is projected to high schooler. The majority of high school students are entering puberty, they are at the age where all problems have to be solved instantly. Puberty is when it very much affects the students' studies development.

Lessons in school to student at high school often forgot the values of Javanese culture, can actually be anticipated in many ways. In the process of learning, both the students and the teachers have the purpose that align so it needs to be combined with the right way of studying so the learning process can proceed as it should be. Learning model is teacher's teaching method in class. There are various way of learning but based on the background stated above the most efficient way is learning based on solving problem or usually called as Problem Based Learning (PBL) [2].

Learning based on problem solving or PBL is a method that was applied by teachers in the learning process at class that projects a problem which Javanese culture being the center of the history lesson. In the execution of learning in class, a teacher decides on a problem that will be solved in the lesson, after that groups with the integration of Javanese culture will be formed so the groups will be able to learn in an interesting way and not leave Javanese culture that will always be expected and preserved. PBL Implementation In History Study Groups Integrated With Javanese Culture.

\section{RESEARCH METHODS}

This research uses descriptive qualitative method with the deepening of research resources directly with reinforced by historical source that is by using literature study as data collecting media and as a step to prove the level of validity of problem under study. The method of qualitative research is basically the research method used to examine the natural object in which the researcher is a key instrument in the technique of collecting data from various ways[3], which can be explained that the focus of this research revolves around the student learning process incorporated in study groups with emphasis on the theme or design of learning in the form of adoption of Javanese culture, and the most appropriate is the Javanese Culture system as one of the focus of model formation and especially on the integration of values understood as one of the derivative forms of culture.

This research is carried out in schools especially at high school level, because history lessons are specifically obtained only at high school level schools, and the object of this research is being reported to high school students in Surakarta. 


\section{RESULT AND DISCUSSION}

The process of learning in school are an element of formal legal that every children have to went through. As of that the learning process should be done by every person involved in the matter of schooling, like teachers, students, administrators, etc. There are steps in learning such as the early step, the main step, and the final step. This step y step are what construct the process of learning in formal legal environment.

To create all of that many students felt burdened. Because in the process of formal education expect students to get the best result so there needs to be a fun way of learning. The teaching method enables the students to learn better and earn the best result. Bruje Joice Weil and Emily Colhoun have reviewed learning methods that is considered useful and try it on the students, because learning methods are a way to organize orientated education on tendency (intelegence-oriented education) and gives the students freedom to self-learn. The key for effectiveness of learning is in training the students to be a reliable learner (more powerful learners) [4].

The opinion above is supported by Eggen and Kauchak (2012:7) who add to the definition of learning methods like specific approachment in teaching that has three characterization: purpose, phase, and foundation [5]. It is clear that in the process of learning there has to be methods of learning for it to looks interesting and not boring, moreover in the process of learning history, because students have already this mindset tht history is a lesson with the most material compared to other lesson. A fun way of learning can make the students think in their own preferred way. The students are also expected to not only receive information therefore makes them passive students but also able to construct the information that was given to them [6].

In applying those lessons there needs to be the right methods of learning, usually adjusted to the condition of the students. Learning methods based on problem solving are a way of learning that is orientated to an analysis of living condition, because many problems can be solved with this learning method. Referring to Barrow's opinion in (Miftahul Huda, 2015:271) stated that this learning method are achieved through process of an understanding and problem resolution [2].

PBL is a learning method that is orientated on theoretical framework of constructivism with the focus of its study being on the problem they have chosen and for that, students did not only have to understand the concept that is relevant to the problem it is centered around but also giving experience of studying that is related to skills of applying scientific method in problem solving and developing critical mindset.

Learning method based on problem solving or PBL in the process of learning at school are often combined with various learning media are useful as an aid in lessons. On this research, learning methods based on problem solving are combined with the integration of Javanese cultures as the identity of the study groups.

The practice of this learning method is done in class that is applying PBL method or problem solving method, after that groups consisted of students are formed, every group are given identities using terms that referred to Javanese culture. Next in the practice, those study groups are expected to be able to help solve a problem that is being coordinated between students in the form of various discussion which is in tune with what the students want. The study group is meant to be the result of teamwork between students that is the main function. Accomplishing tasks that was 
given is the other function in which to achieve the goal in learning history. The study groups that was formed contain sacred cultural values. Those values have philosophical meaning that can be the foundation of a study process in high school history study groups in Surakarta. In Javanese family there is a philosophy "tuno satak bathi sanak, sedumuk batuk senyari bumi, mangan ra mangan seng penting kumpul, dan sebagainya" that can be used as a name of history study group. Other than that, its implementation form has the shape of gugur gunung or kerja bakti such as applied by Javanese people. Javanese people believe in working together to finish their job with gugur gunung or kerja bakti. Kerja bakti is when people reach certain goals with working together. Users of that Javanese term above can raise many function for students that is applying it. It can be used as motivation to study history. To achieve the main goals in study groups is to up the result of student's study so it can be used as a push or trigger for studying, primarily for students with different ways of learning.

It can also be used as an introduction of the noble Javanese culture. Nowadays many children are being subjected to globalization. Globalization made them forgot their identity and inheritance from their ancestors [7].But with applying this learning method it is hoped that it can give other benefits and principles to the children. As it was understood that Javanese cultures are cultures that uphold the values of tradition that is being applied by the citizens (Idrus, 2000). Since childhood children were taught of humility, fear, and hesitancy so it made them have low confidence, les initiative, not spontaneous, and less expressive the result is that in the future they will be less developed because fearing to explore and express their own selves.

As the main mission in the process of learning at school is to liven up lesson so that certain goals can be achieved. As stated by M. Sobry Sutikno that the definition of learning methods as conceptual structure that describes systematic procedure and organizing study experience to achieve certain study goals [8]. Through the process of interesting way of learning students can get a new way to learn that is more fun, meaningful, and efficient. Moreover there are values in applying the principles or learning methods syntax that fit with the process that has been planned. The application of Javanese culture integration in learning, students can learn Javanese culture as a motivation to reach the best result.

\section{CONCLUSION}

High school students are students that can be categorized as unstable because at their ages they get many influences. Influences the got will not always make their life better because many of those influences are negative, so there have to be a solution to those challenges that they faced.

Javanese cultures are one of noble cultures, cultures that have many lessons, values, and norms, so it is proper that it is used to answer many problem the students have. The practice of Javanese culture can be done anywhere but is it used on high school student the best place is at school. School is where students, teachers, and administrators to meet and achieve their purposes. Students are at school to gain knowledges through the process of learning. In the process it can also be integrated with Javanese cultures to solve many problems. Integration process can be done with the right way of learning. The only method that can solve many problems is Problem Based Learning (PBL). Learning with PBL method is to form several study groups, 
through this groups Javanese cultures term can be integrated as their group name. Group name with this terms are expected to give the 'khasanah' of education to students.

Students that learn together in a group will remember Javanese terms in hope that it will deepen their knowledge about Javanese cultures. Students that understand Javanese cultures are expected to have good character and be able to achieve what has been planned.

\section{REFERENCES}

[1] Koentjaraningrat. 1994. Kebudayaan Jawa. Jakarta: Balai Pustaka.

[2] Huda, Miftahul. 2013. Model-Model Pengajaran dan Pembelajaran: Isu-Isu Metodis dan Paradigmatis. Yogyakarta: Pustaka Pelajar.

[3] Sugiono. 2014. Metode Penelitian Kuantitatif, Kualitatif, dan Kombinasi (Mixed Methods). Bandung: Alfabeta

[4] Joice, Bruce, Marsha Weil \& Emily Calhoun. 2011. Model's of Teaching, Model-Model Pembelajaran. Jogjakarta: Penerbit Pustaka Pelajar.

[5] Eggen, Paul, dkk. 2012. Strategi dan Model Pembelajaran Mengajarkan Konten dan Keterampilan Berfikir. Jakarta: Indeks.

[6] Ornstein, Allan C. And Francis P. Hunkis. 2013. Currikulum Foundation Pricipels, and Issue. USA: Pearson Education

[7] Endraswara, Suwardi. 2003. Falsafah Hidup Jawa. Jogjakarta: Cakrawala

[8] M. Sorby Sutikno. 2014. Belajar dan Pembelajaran. Bandug: Prospect

[9] (2016) Kamus Besar Bahasa Indonesia Luar Jaringan. Pusat Bahasa Kementrian Pendidikan Nasional.

[10] Adair C.K. 1999, Cracking The glass ceiling : Factors Influence Women's Atainment of Senior Excecutive. Disertation. USA

[11] Baay, Reggie.2009. Nyai dan pergundikan Hindia Belanda. Jakarta: Komunitas Bambu.

[12] Blumberg, P. 2000. Evaluating the evidence that problem-based learners are self-directed learners: A review ofthe literature. In D. H. Evensen \& C. E. Hmelo. (Eds.), Problem based learning: A research perspectiveon learning interactions (pp. 199-266). Mahwah, NJ: Lawrence Erlbaum Associates.

[13] Brookfield, S.D. 1987. Developing critical thinkers. Challenging adults to explore alternativeways of thinking and acting. Milton Keynes: Open University Press.

[14] Christian\&Ardhian. 2008. Kuasa wanita Jawa. Yogyakarta: PT LKIS Pelangi Aksara.

[15] David Arnold . 2010. Inquiry Learning: Mking History Active.Ethos : term 2. Pp 20 Dede, C. (Eds.). (1998). ASCD Yearbook: Learning with T echnology. Alexandria,VA :Association forSupervision and Curriculum Development

[16] Geertz, Hildered. 1982. Keluarga Jawa. Jakarta: Grafiti Press

[17] Hellwig, Tineke. 2007. Citra Kaum Perempuan di Hindia Belanda. Jakarta: Yayasan Obor Indonesia

[18] Heru Santoso, Budiyanto. 1983. Simbolisme dalam Budaya Jawa. Yogyakarta: Hanindita

[19] Koes Ismaniah, GRAy. 2013. Mau Kemana, Kraton Kasunanan Surakarta. Jakarta: Kata Hasta Pustaka

[20] MacKnight, C.B. 2000. Teaching critical thinking through online discussions. EducauseQuarterly, 4, 38-41.

[21] Ricklefs, M. 1991. Sejarah Indonesia Modern. Yogyakarta: UGM Press

[22] Riyanto. 1966. Hukum Peradilan di Praja Kejawen. UNS: Fakultas Sastra dan Seni Rupa

[23] Sitterly, C. Ed. 1994. Tehe Female Enterpreneur, The Crisp Small Businnes Enterpreneurship Series

[24] Soedarmono. 2006. Mbok Mase Pengusaha Batik di Laweyan SoloAwal Abad ke-20. Jakarta: Warna-warni Indonesia

[25] Suryakusuma, Julia.2012. Agama, Seks dan Kekuasaan. Jakarta: Komunitas Bambu Sutikno.

[26] M. Sobri. 2014. Metode dan Model-Model Pembelajaran Menjadikan Proses Pembelajaran Lebih Variatif, Aktif, Efektif, dan Menyenangkan. Lombok: Holistika. 